ARTIGOS

\title{
Do potencial à ação: $o$ engajamento de jovens em partidos políticos
}

\section{From potential to action: youth engagement in political parties}

Ana Karina Brenner (i)

(i) Universidade do Estado do Rio de Janeiro - UERJ, Rio de Janeiro, RJ, Brasil, https://orcid.org/0000-0002-0778-3525. anakbrenner@yahoo.com.br

Resumo: Estudos sobre engajamento, como os de Fillieule, Oliveira e outros, recomendam que a compreensão de tais processos deve se fundamentar em análises diacrônicas e sincrônicas, combinando (i) a construção de disposições duráveis ao engajamento com (ii) o reconhecimento das redes de relacionamento e (iii) as experiências que permitem transformar tais disposições em engajamentos efetivos. Neste artigo, exploram-se esses aspectos da constituição do fenômeno do engajamento juvenil por meio da análise de entrevistas narrativas realizadas com 21 jovens estudantes do Rio de Janeiro, militantes de partidos políticos, as quais permitiram identificar nexos entre disposições construídas ao longo da trajetória pessoal e familiar, em diferentes processos educativos, e redes de relacionamento e eventos que acionaram tais disposições, transformando-as em efetiva militância política.

Palavras-chave: Sociologia da Juventude, socialização, participação da juventude

Abstract: Studies on political engagement, like Fillieule's, Oliveira's and others, recommend that the understanding of such processes must be based on diachronic and synchronic analyses, combining (i) the construction of lasting dispositions to engage with (ii) the recognition of social networking and (iii) the experiences that allow for the transformation of such provisions into effective engagement. This article explores such aspects of the constitution of the youth engagement phenomenon through the analysis of narrative interviews conducted with 21 young students from Rio de Janeiro, all of whom are political party activists. The analysis allowed us to identify links between dispositions built along their personal and familial trajectories, through various educational processes, and the social networks and events that triggered such dispositions transforming them into effective political activism.

Keywords: Youth Sociology, socialization, youth participation 


\section{pro.posıções

http://dx.doi.org/10.1590/1980-6248-2016-0120

O artigo revisita dados de tese de doutorado, defendida em 2011, que tratou do engajamento partidário de jovens. Ainda são poucos os estudos sobre o tema no Brasil, mas há avanços em diferentes áreas das ciências Humanas e Sociais no sentido de buscar compreender diferentes formas e conteúdos do engajamento juvenil, seja em partidos políticos (Brenner, 2011; Silva, 2015) ou organizações associativas diversas (Moreno, 2014; Ruskowski, 2012). O ainda incipiente campo de estudos do engajamento juvenil no Brasil foi verificado na realização do Estado do Conhecimento (1999-2006) ${ }^{1}$, especificamente no artigo que tratou dos jovens na interface com a politica, de Sposito, Brenner e Moraes (2009), que não encontrou qualquer trabalho sobre jovens militantes de partidos. As dissertações e as teses que tratavam dos jovens na interface com a política diziam respeito a outros espaços e formas de eles se relacionarem com a política e o político. Se tomarmos como referência os engajamentos não apenas de jovens, mas também de adultos, amplia-se o leque de estudos, mas ainda assim, concordando com Seidl (2014) em artigo que aborda elementos para discussão sobre engajamentos nos estudos brasileiros, "se tem muito caminho pela frente" (p. 55).

A militância pode ser entendida como resultado de distintos processos de socialização familiar, escolar, religiosa, no trabalho, etc. que, associados a percursos de vida - experiências sociais, políticas e profissionais - e à participação em organizações e movimentos sociais podem produzir efetiva ação de engajamento.

Associo-me, assim, a uma visão da sociologia da militância que toma o engajamento como processo. Um processo que alia fatores de "predisposições à militância, da passagem à ação, das formas diferenciadas e variáveis ao longo do tempo adquiridas pelo engajamento, da multiplicidade dos engajamentos ao longo do ciclo de vida e da retração ou ampliação dos engajamentos" (Fillieule, 2001, p. 201).

A Sociologia, para além de definir o conceito de engajamento, busca compreender as razões e os motivos que levam um indivíduo a se engajar em associações, grupos e movimentos sociais. Não se nasce militante, torna-se um, e, em torno dessa ideia, constituíram-se algumas correntes de explicação sociológica ao engajamento.

A construção de disposições duráveis, ligadas ao conceito de habitus, de Bourdieu (1983, 1989), é uma das correntes sociológicas que procura explicar as razões e os motivos do

\footnotetext{
${ }^{1}$ Levantou a produção discente (dissertações e teses) sobre juventude no período de 1999 a 2006 nas áreas de Educação, Ciências Sociais e Serviço Social.
} 


\section{pro·posıções \\ $e$-ISSN 1980-6248}

http://dx.doi.org/10.1590/1980-6248-2016-0120

engajamento. Para Bourdieu, as disposições para o engajamento político estão ligadas às desigualdades das condições de origem e dos capitais sociais, econômicos, culturais e políticos dos agentes sociais. Os sujeitos situados nas posições inferiores de classe estão mais predispostos ao engajamento, devido à busca por diminuir a desigualdade de acesso aos bens sociais e culturais disponíveis na sociedade. Essa explicação, contudo, não permite compreender de que maneira as disposições se transformam em ação prática, nem mesmo as razões do engajamento de sujeitos de classes superiores ou, ainda, do porquê de alguns se engajarem e outros não, quando disposições ao engajamento se encontram presentes.

A tradição sociológica do interacionismo simbólico da Escola de Chicago torna central o papel das redes de interações estabelecidas pelo sujeito no momento presente, significando contato com espaços e grupos com os quais se identifica, e é capaz de construir algum tipo de reciprocidade. Essas redes possibilitam seu engajamento. A identificação com o grupo com o qual estabelece relação e a equação positiva entre investimento realizado na militância e as compensações materiais, pessoais e simbólicas que se pode produzir estão presentes e explicam o processo de engajamento (Brenner, 2014).

Estudo de McAdam e Paulsen (1993) mostra que os laços anteriores e a identificação subjetiva isoladamente não são suficientes para explicar o engajamento em redes e movimentos. É preciso considerar um mosaico de fatores que contemplam a rede de interações do presente e os processos de socialização precedentes. Nesse sentido, a combinação da análise do processo de socialização (Dubar, 2005; Maurer, 2000; Müxel, 2008) - diacrônico - e das redes de relacionamento e experiências do presente - sincrônico - é necessária para compreender não apenas como se constroem disposições - propensão ao engajamento -, mas também como elas se transformam em prática efetiva. Em perspectiva integrada das teorias, há que se considerar a participação individual como produto dos processos de socialização e das experiências da vida pessoal, os contextos interacionais e as biografias.

Para Klandermans (1984), o envolvimento em algum tipo de movimento é o resultado de processos de decisão racional, através dos quais os indivíduos pesam custos e benefícios da participação. A relação entre custos e benefícios do engajamento não só é fundamental para explicá-lo, como também exerce papel decisivo. Ainda segundo o autor, uma pessoa se engajará, se conhecer oportunidades para fazê-lo, se for capaz de lançar mão de uma ou mais 


\section{pro.posıções

oportunidades e estiver disposta a isso. Em estudo posterior, Klandermans e Oegema (1987) afirmam haver quatro aspectos distintos para a concretização do engajamento: (i) formação de potenciais disposições para o engajamento; (ii) formação e ativação de redes de mobilização; (iii) ativação da motivação para o engajamento e (iv) remoção das barreiras à participação. Os dois primeiros aspectos precisam estar presentes para que o terceiro seja ativado, e, quanto mais motivado estiver o indivíduo, maiores as barreiras que ele será capaz de transpor para concretizar seu engajamento.

Os mesmos autores reiteram, ainda, que os movimentos sociais ou grupos precisam acessar redes para que as pessoas possam se tornar alvo do potencial mobilizador desses grupos ou movimentos. No caso do recrutamento de jovens para os partidos políticos, as redes escolares e as universitárias se apresentam como instâncias privilegiadas de recrutamento de militantes.

McAdam e Paulsen (1993) indicam que os laços sociais são importantes para o ativismo, porém não explicam por que e como tais laços operam na realização do engajamento. Mostram, com exemplo na pesquisa de Klandermans e Oegema (1987), que há muito mais pessoas com disposições ao engajamento do que aquelas efetivamente engajadas. Relacionam, então, a influência de fatores estruturais para o engajamento: se não houver estruturas que exponham as pessoas à participação (espaços, grupos organizados localizáveis), as disposições terão pouca importância, porque permanecerão inativas.

McAdam e Paulsen (1993) reforçam, assim como Klandermans e Oegema (1987), a importância dos vínculos interpessoais e a associação a outras organizações: "Redes interpessoais densas encorajam a extensão de um convite à participação e reduzem a insegurança sobre ela" (McAdam \& Paulsen, 1993, p. 644, tradução nossa). Isso parece fato para o recrutamento realizado pelos partidos políticos no movimento estudantil: não há, necessariamente, laços interpessoais fortes, mas a rede escolar parece dar suporte e segurança aos estudantes para a participação em algo que ocorre dentro do espaço escolar ou universitário.

Abordar o tema em perspectiva integrada de análise também implica considerar que as redes de relações e os espaços de inserção só produzirão efeitos para fins de engajamento, se já encontrarem as disposições individuais para tal. O pertencimento anterior a redes formais 


\section{pro·posıções

ou informais de participação também contribui para o início ou a manutenção do engajamento, na medida em que "acumulam experiências" e servem como espaços de socialização, agregando-se às socializações anteriores, aumentando os esquemas de ação dos sujeitos e as disposições para a ação.

Pudal (2009) afirma que se tornar militante

é um processo extremamente complexo, no qual se combinam diferentes histórias: a história das origens sociais e das socializações específicas daqueles que militam; do sistema escolar e de seu lugar na sociedade; dos próprios recursos físicos, intelectuais e psicológicos desses sujeitos; também dos contextos de investimentos militantes; e, finalmente, a história dos riscos e das etapas de uma carreira militante. (p. 133)

A propósito das possibilidades do engajamento, Fillieule (2001) ilustra os condicionantes do contexto, apontando para o fato de que a "oferta" de espaços de militância de extrema esquerda na França, especialmente após a vitória socialista nas eleições presidenciais de 1981, escasseou. Teria havido um deslocamento do "sujeito revolucionário", e isso explicaria as razões de o militantismo político radical de jovens ter se deslocado das organizações políticas clássicas em direção a um investimento espontaneísta contracultural (Pécchu, 2001). Esse exemplo demonstra que as disposições, as biografias, os capitais diversos podem ser constrangidos por um contexto que condiciona as escolhas individuais.

\section{Algumas considerações metodológicas}

Em pesquisas sobre militância, quer de jovens ou de adultos, pesquisadores (Agrikoliansky, 2001; Cicchelli, 2009; Fillieule, 2001; Gaxie, 2002) são entusiastas do uso de abordagens longitudinais nos estudos sobre a construção das disposições para o engajamento e das carreiras militantes. Nessa perspectiva, seria possível acompanhar militantes e perceber, “em tempo real", inflexões, rupturas, mudanças e variações de investimentos na militância. Dessa forma, a reconstrução das experiências de militância ocorreria através das diversas narrativas recolhidas ao longo do tempo, as quais se referem sempre a um tempo vivido mais próximo ao tempo presente e não àquilo que se passou há muito tempo.

No caso dos jovens estudantes engajados em partidos políticos, foi possível entrevistálos em dois momentos distintos, com intervalo de um ano, e as narrativas aqui sistematizadas 


\section{pro·posıções \\ $e$-ISSN 1980-6248}

http://dx.doi.org/10.1590/1980-6248-2016-0120

e analisadas são produto dessa reconstrução de experiências de militância. Ainda que pareça pouco, a distância de um ano na vida de jovens que se encontram na transição entre o percurso escolar de nível superior e o início de carreiras profissionais é bastante significativa e mostrou-se suficiente para apontar nuances no engajamento.

As entrevistas biográficas são o instrumento primordial para levantar a rede contínua de interpretações subjetivas que guiam as condutas do indivíduo (Fillieule, 2001) e foram adotadas neste estudo. Dubar (2005) sugere que o conjunto de entrevistas e informações coletadas permite revelar, de forma indutiva, tipos de argumentação, categorias específicas de mobilizações, agenciamentos típicos.

Entre os anos de 2009 e 2010 foram realizadas entrevistas com jovens estudantes de uma universidade pública do Rio de Janeiro (Brenner, 2011), selecionados, por meio de questionário e por indicações dos próprios entrevistados, jovens militantes, a partir de alguns critérios que garantissem um razoável grau de diversidade no perfil econômico e cultural, equilíbrio de sexo no grupo, bem como diversidade de partidos políticos. A seletividade dos cursos universitários foi usada como parâmetro para assegurar diversidade socioeconômica. Os cursos mais seletivos (Medicina, Direito, Engenharias, por exemplo), em geral, agregam estudantes de perfil socioeconômico mais elevado; os de baixa seletividade (Ciências Sociais, História, Geografia, Enfermagem, entre outros), normalmente, têm predominância de estudantes de camadas médias e baixas e populares. Ainda que essa não seja uma regra geral, a utilização da seletividade de cursos mostrou-se eficiente na obtenção de uma diversidade de perfis socioeconômicos ${ }^{2}$.

As sondagens realizadas sobre a militância partidária de jovens no Rio de Janeiro indicaram que os partidos considerados de centro ou direita (como PSDB, PMDB, DEM, entre outros) não possuem militantes nucleados ou ativos nas universidades públicas do estado, entretanto um núcleo do DEM foi encontrado em uma importante universidade particular. A decisão por escolher uma universidade e não os próprios partidos como campo de pesquisa se deu pela necessidade de ter um ponto de encontro de jovens com engajamento político, pois, caso contrário, ainda seria necessário “filtrar" os que são apenas filiados e

\footnotetext{
2 Para descrição mais detalhada da metodologia, ver Brenner (2011).
} 
aqueles que são efetivamente engajados ${ }^{3}$. Escolhida a universidade na qual se assentaria o campo de estudo, aplicou-se aos participantes de um encontro de estudantes um questionário, que tinha como questão central a pergunta "você é engajado em algum partido político?", além de outras relacionadas a perfil socioeconômico, curso universitário frequentado e partido de engajamento. Para a realização das entrevistas, selecionou-se a maior variedade possível de partidos a partir dos questionários e das indicações fornecidas por outros jovens entrevistados, numa estratégia de bola de neve, a fim de assegurar equilíbrio de sexo e variedade de partidos. Foi possível, então, entrevistar 21 jovens, sendo 11 homens e 10 mulheres, de 5 partidos, todos identificados como de esquerda.

Há jovens representantes das chamadas elites intelectuais ${ }^{4}$, de classes médias ${ }^{5}$ e de camadas populares ${ }^{6}$ mas nenhum de elites econômicas ou políticas. Há equilíbrio numérico de jovens de classes médias e elites intelectuais (12) e classes populares (9); mas há predomínio de homens entre as camadas populares (6 homens e 3 mulheres) e de mulheres entre as classes médias (7 mulheres e 5 homens).

O perfil dos 21 jovens $^{7}$ pode ser sintetizado no Quadro 1:

\footnotetext{
${ }^{3}$ Diferencia-se engajamento - participação sistemática em atividades do partido - de filiação formal - assinatura de ficha e registro de filiado junto ao TRE.

${ }^{4}$ Pais professores de universidades públicas com formação em nível de mestrado ou doutorado.

5 Famílias com alta escolarização, empregos de alta qualificação (funcionários públicos ou privados de nível superior) e cujo capital econômico se situa em padrões médios de renda - na maioria dos casos, o capital cultural é o determinante mais forte da condição de classe, mas, em ao menos um deles, é o capital econômico o principal fator de inserção entre as classes médias.

6 Aqueles cujos pais chegaram, no máximo, até o Ensino Médio realizam trabalhos de baixa ou média qualificação (servidores públicos ou funcionários da iniciativa privada de nível básico, autônomos - como taxistas e pescadores -, militares de baixa patente, mulheres do lar).

7 Os nomes dos jovens foram alterados a fim de preservar suas identidades, e pela mesma razão a universidade em que estudam tampouco será identificada.
} 


\section{pro·posıções

Quadro 1 - Perfil dos jovens entrevistados

\begin{tabular}{|c|c|c|c|c|}
\hline Nome & Seletividade do curso & Origem de classe & Partido & Idade \\
\hline Poliana & Alta (Direito) & Média & PSTU & 25 \\
\hline Denise & Média (Ciências Sociais) & Média & PSTU & 29 \\
\hline Marina & Média (Ciências Sociais, mestranda) & Elite intelectual & PSOL & 28 \\
\hline Antônia & Média (História) & Média & PT & 22 \\
\hline Núbia & Média (Ciências Sociais) & Elite intelectual & PT & 21 \\
\hline Tamara & Baixa (Serviço Social) & Popular & PSTU & 27 \\
\hline Cíntia & Baixa (Serviço Social) & Média & PT & 25 \\
\hline Guinevere & Baixa (Pedagogia) & Média & PT & 28 \\
\hline Fernanda & Baixa (Enfermagem) & Popular & PSOL & 22 \\
\hline Ademir & Alta (Economia) & Elite intelectual & PSOL & 21 \\
\hline Tuco & Alta (Engenharia) & Média & PDT & 28 \\
\hline Erivelto & Alta (Direito) & Popular & PDT & 29 \\
\hline Luciano & Média (História) & Média & PT & 25 \\
\hline Julião & Média (História) & Popular & PT & 23 \\
\hline Cláudio & Média (História) & Média & PSOL & 28 \\
\hline Norberto & Média (Geografia) & Média & PSOL & 29 \\
\hline Roberto & Média (Psicologia) & Popular & PSOL & 21 \\
\hline Mariano & Média (Ciências Sociais) & Popular & PSOL & 24 \\
\hline Silvano & Média (Letras) & Popular & PSOL & 27 \\
\hline Welington & Baixa (Estatística) & Popular & PCdoB & 21 \\
\hline Joana & (Ensino Médio) & Popular & PDT & 24 \\
\hline
\end{tabular}

Fonte: elaborado pela autora

As entrevistas realizadas foram transcritas, e seus conteúdos agrupados em categorias a partir dos eixos analíticos da pesquisa relacionados com socializações, construção de disposições ao engajamento, espaços e práticas de militância e deslocamentos do engajamento em partidos políticos: perfil, experiências familiares, experiências escolares, militância para dentro e militância para fora do partido.

\section{Socializações políticas nas experiências familiares}

Os processos e os perfis de socialização familiar dos jovens que compuseram o grupo pesquisado serão apresentados aqui de maneira bastante sucinta, visto que já foram desenvolvidos em mais detalhes no artigo "Jovens e militância política" (Brenner, 2014), mas são importantes para a compreensão dos nexos entre processos de socialização que produzem disposições ao engajamento e a transformação desses em ação militante. Assim sendo, convém retomar alguns aspectos centrais das socializações familiares dos jovens entrevistados. As experiências vividas pelos pais e a origem de classe das famílias são significativas para 


\section{pro·posıções \\ $e$-ISSN 1980-6248}

http://dx.doi.org/10.1590/1980-6248-2016-0120

compor o cenário no qual ocorreu a socialização dos jovens, pois constituem a cultura política e as visões de mundo que os pais buscaram transmitir a seus filhos e sobre as quais os filhos se apoiaram, acrescentando elementos de suas próprias experiências, para construir seus caminhos militantes.

O grau de engajamento dos pais em movimentos, partidos políticos ou outras modalidades de participação, ou ainda o interesse deles em relação à política, são significativos para a análise dos processos de socialização política dos jovens militantes. A construção de disposições para o seu engajamento encontra, na cultura política e militante dos pais, um importante fundamento (Brenner, 2014).

É possível agrupar os 21 jovens entrevistados em 3 distintos grupos, ao tomarmos como referência práticas familiares que produziram socialização política e contribuíram para a produção de disposições ao engajamento: (i) jovens cujos pais eram politicamente engajados; (ii) jovens cujas famílias manifestavam algum interesse por questões políticas e estavam abertas ao debate político no âmbito familiar e (iii) jovens cujas famílias não demonstravam, segundo seus relatos, qualquer interesse e nunca tomaram posição em questões políticas.

O grupo de jovens filhos de pais engajados reúne, coincidentemente, aqueles (Ademir, Núbia e Marina) cujos pais representam as elites intelectuais referidas anteriormente. Além desses, os pais de Julião também eram engajados politicamente e representam a exceção nesse grupo, por serem oriundos de classes populares. Os jovens Ademir, Núbia e Marina reúnem, a um só tempo, alto capital cultural, as mais altas rendas entre as famílias dos jovens entrevistados e capital político acumulado pelos pais através de engajamentos em atividades partidárias. Para os jovens desse grupo, os pais tiveram papel significativo em sua formação política, ao narrar suas experiências como militantes, compartilhar valores e práticas políticas com os filhos e, ao manter, dentro de casa, diálogo constante sobre acontecimentos cotidianos e ligados à vida política do país ou da cidade em que moravam.

O grupo de jovens de famílias que manifestavam algum interesse político é o que agrupa o maior número de jovens e nele se encontram aqueles cujos pais não eram engajados em partidos ou associações de moradores e afins, mas tinham alguma permeabilidade ao debate político em suas famílias. A porosidade das famílias para aquilo que se refere à política ou a disposições ao engajamento se expressa de diversas formas: pais que manifestavam suas 


\section{pro.posıções \\ $e-I S S N$ 1980-6248}

http://dx.doi.org/10.1590/1980-6248-2016-0120

preferências partidárias e argumentavam a favor de seus candidatos nos momentos de campanhas eleitorais; familiares que, por força dos cargos públicos que ocupavam, discutiam situações e conjunturas políticas; pais que participavam em ações ou organizações filantrópicas, entre outros. Nesse grupo estão os jovens Erivelto, Poliana, Cláudio, Norberto ${ }^{8}$, Roberto, Mariano, Antônia, Tamara, Cíntia, Joana e Fernanda. Cinco dos jovens desse grupo de famílias permeáveis à política são de classes médias e seis, de classes populares. Não se percebe, nesse grupo, distinções claras entre a socialização familiar de um e de outro grupo social. Cláudio e Mariano, por exemplo, descreveram práticas e valores familiares bastante similares. Ambos construíram referências políticas opostas às descritas pelos pais, sendo o primeiro de classe média e o segundo de classe popular.

No caso de Cláudio, a influência familiar é mais óbvia, visto que membros de sua família haviam tido vinculação com a política partidária - um tio-avô senador, falecido antes de o jovem nascer, e o pai, que foi candidato a vereador sem, contudo, estabelecer fortes vínculos com partido político -, mas o jovem afirmou que sempre foi crítico aos posicionamentos conservadores da família. Para os demais jovens desse perfil, a permeabilidade das famílias a questões ligadas à política ou ao engajamento é mais sutil. Tias que, sendo funcionárias públicas, mantinham conversas sobre questões políticas, disputas de poder, etc. Um pai, ex-funcionário de empresa estatal que foi privatizada, também abordava temas relacionados com o mundo da política institucional. A adesão eleitoral a determinadas figuras da política local ou nacional também demonstra algum nível de permeabilidade das famílias ao tema da política, como foi o caso de Mariano - nascido em estado da região norte do País mudou-se para o Rio de Janeiro para cursar faculdade - cujo pai teria sempre se referido aos candidatos da família Sarney, defendido-os e votado neles, ainda que não filiado a qualquer partido, nem envolvido diretamente em campanhas políticas ou outra atividade associativa.

O terceiro grupo é o de jovens de famílias não engajadas e é o menor, reunindo seis deles que não relataram qualquer tipo de engajamento, mobilização ou expressão de opiniões políticas por parte de seus pais ou familiares. Nesse grupo, estão os jovens Tuco, Luciano,

\footnotetext{
${ }^{8}$ Apesar de uma certa porosidade da família de Norberto em relação à política, expressa pela participação dos pais em campanhas políticas petistas, foi a experiência de trabalho que abriu caminho para sua militância partidária. Sua socialização política será marcada, portanto, mais por outros espaços de socialização do que pela família e pela escola.
} 


\section{pro.posıções

Denise, Guinevere, Welington e Silvano. No que se refere à posição de classe, quatro são de classe média e dois são de camadas populares.

O jovem Welington informou, assim como Julião e Claudio, gosto por leitura, mas em seu caso lia o que estava disponível em sua escola ${ }^{9}$ - em geral romances policiais de Agatha Christie. Denise afirmou que sua família tinha valores muito rígidos, e a noção de ética e correção de comportamento era muito valorizada. Segundo a jovem, esses valores transmitidos pela família foram encontrados também no partido em que milita, e é a isso que ela atribui seu engajamento político, ou seja, ao fato de o partido defender valores adquiridos por ela em família.

Apesar de informarem o não engajamento de seus pais ou familiares, os jovens desse último grupo referem-se a algumas práticas ou valores familiares que, apesar de não se articularem diretamente com o universo da política, contribuíram para a transmissão de valores que foram posteriormente acionados, no momento do engajamento, e que foram atualizados a partir das práticas militantes.

\section{Socializações e redes de relacionamento que se concretizam no processo de escolarização}

Os jovens, acima agrupados segundo perfis de socialização familiar, tiveram, em seus percursos escolares, socializações políticas que podem ser caracterizadas também de acordo com as experiências familiares de socialização política ${ }^{10}$. Assim, os jovens filhos de pais engajados tiveram experiências escolares aqui caracterizadas como em continuidade com a socialização familiar, ou seja, em continuidade aos valores e aos comportamentos políticos transmitidos em família. Os jovens de famílias que manifestavam algum interesse político tiveram suas experiências escolares caracterizadas como associadas à pouca socialização

\footnotetext{
9 Claudio e Julião informaram ter tido acesso a acervo literário em casa, o segundo com maiores restrições financeiras à aquisição de livros, mas tendo esses como investimento preferencial de seu pai.

${ }^{10}$ Ver Brenner (2014), para maior detalhamento sobre as socializações escolares.
} 


\section{pro·posıções

política familiar; e os de famílias não engajadas tiveram experiências escolares aqui caracterizadas como experiências escolares que socializaram para a política ${ }^{11}$.

A escola é espaço-tempo de socialização que representa novidade em relação à socialização que ocorre na família. É lugar de vivência de novas experiências, de construção de novas amizades, de convivência com o outro, muitas vezes lugar de convívio com a diversidade e a diferença. $\mathrm{Na}$ escola, crianças e jovens se relacionam com seus pares de idade e com adultos de diferentes idades, especialmente os professores. Além de espaço de socialização, pode também ser lugar onde ocorrem as primeiras aproximações com grupos militantes organizados, pela existência de grêmios e outras formas de mobilização estudantis. A escola pode ser, por isso, além do lugar de socialização, também espaço de concretização da militância de jovens (Brenner, 2014).

Para os jovens cujas famílias tinham experiências de engajamento, o processo de escolarização deu-se como continuidade da socialização familiar e do prosseguimento da construção de disposições ao engajamento. Isso não significa dizer que as escolas tenham transmitido exatamente os mesmos valores políticos que suas famílias, visto que os conteúdos da socialização podem variar. Tournier (1997) já chamava atenção para o fato de as famílias escolherem as escolas de seus filhos, conforme seus valores e princípios, mas que tais demandas estão sempre condicionadas a fatores estruturais como oferta de vagas, habilidades de escolha dos pais e também disponibilidade de recursos financeiros para realizar determinadas opções.

Professores de disciplinas específicas e grêmios estudantis foram apontados pelos jovens como influências importantes para a construção do caminho que os levou à militância partidária. Leituras, por indicação de professores ou busca própria em função de interesses específicos, também foram citadas como elementos significativos das experiências escolares para construção de valores políticos e de disposições ao engajamento. Uma greve, por exemplo, aproximou Ademir do grêmio estudantil de sua escola e, no aprofundamento da experiência no grêmio, tornou-se presidente dele aos 14 anos de idade. Marina disse que não havia grêmio atuante em sua escola, mas que nela se valorizavam e incentivavam condutas que

${ }^{11}$ As experiências escolares não socializam, necessariamente, para a política. O que aqui está caracterizado são percursos de jovens que se engajaram politicamente e, ao terem suas narrativas relacionadas com experiências familiares e escolares analisadas, permitiram concluir que aquele grupo de famílias não engajadas politicamente fora, de fato, socializado para a política nas escolas que frequentaram. 


\section{pro.posıções \\ $e$-ISSN 1980-6248}

http://dx.doi.org/10.1590/1980-6248-2016-0120

se aproximavam daquilo que vivia em família: respeito ao próximo e à diversidade, direito à livre expressão. Julião se referiu às aulas de História e Geografia como politizantes, em função das práticas de seus professores, que faziam das aulas um processo dialógico e crítico.

Para os jovens de experiências escolares associadas a pouca influência política familiar, a escola teve papel mais significativo no sentido da socialização política e da produção de disposições ao engajamento, na medida em que as famílias tiveram menor incidência nesse processo. Ou seja, em que pese a menor influência familiar, a escola apareceu como instituição fundamental na socialização política e construção de disposições ao engajamento.

Cláudio, por exemplo, falou da grande influência de um professor de História que, desde a $5^{\text {a }}$ série do Ensino Fundamental, realizava debates com a turma, organizava passeios, visitas a museus. Cláudio foi dos poucos jovens a relatar atividades culturais na escola que foram significativas para a construção de disposições ao engajamento. Sua escola organizava feiras de poesia, onde ele apresentava sua obra e também vendia camisetas que produzia, com estampas variadas - Che Guevara, por exemplo.

Cíntia foi outra jovem a relatar algo parecido. Encontrou na escola espaço para expressão e afirmação de sua orientação sexual, e foi a sensação de se sentir acolhida e não discriminada por sua homossexualidade que a aproximou de alunos do grêmio. Nesse caso, o espaço escolar permitiu, por meio do grupo de colegas, a expressão de sua identidade e, através disso, possibilitou a construção de disposições ao engajamento.

As narrativas desses jovens, de famílias com alguma proximidade com a política, mas nenhum engajamento político, mostram a diversidade de caminhos trilhados na construção de disposições ao engajamento. A socialização política realizada de maneira mais difusa nas famílias parece estimular uma continuidade da socialização política no espaço escolar, mas as dinâmicas pessoais dos sujeitos também colaboram para a construção de valores e comportamentos políticos que serão acionados no momento do engajamento partidário.

No caso dos jovens cujas experiências escolares socializaram para a política, além do convívio com determinados professores ser novamente apontado como significativo para tal, eventos pontuais, mas cuja abrangência extrapolava o âmbito escolar, foram descritas como relevantes. Greves escolares, mobilizações antiprivatização nos tempos do governo de Fernando Henrique Cardoso, ou solidariedade relacionada ao massacre de Eldorado de 


\section{pro·posıções

Carajás, revelaram-se experiências que articularam o espaço-tempo da escola com outras formas de organização social; ou seja, todos foram eventos que afetaram os jovens participantes deste grupo de experiências escolares que socializaram para a política. Acontecimentos como esses foram motivadores da mobilização e do engajamento dos jovens. Para aqueles que já tinham disposições anteriormente construídas, tais eventos acabaram representando a porta de entrada para a concretização do engajamento, ou seja, configuraramse no espaço-tempo de transformação das disposições em ação prática. Para aqueles sem disposições anteriores, como é o caso de Silvano, esses eventos produzem socialização política e constroem disposições logo transformadas em ação prática.

Assim, as redes de interações estabelecidas na escola ou por meio das dinâmicas escolares, que colocam o indivíduo em contato com espaços e grupos com os quais se identifica e é capaz de construir algum tipo de reciprocidade, tornam o engajamento possível.

\section{Socialização política para além da família e da escola}

Família e escola são importantes instituições de socialização política, mas, sabidamente, não são as únicas ${ }^{12}$. Alguns jovens tiveram outros espaços de socialização política que configuraram disposições ao engajamento. Para Roberto, por exemplo, a experiência religiosa foi a mais significativa para a formação de valores políticos e de disposições ao engajamento e, posteriormente, a experiência vivida em um cursinho prévestibular comunitário. Para o jovem, a socialização política e a construção de disposições para o engajamento ocorreram no mundo do trabalho. E para Tamara as disposições para o engajamento foram construídas a partir de diversas e difusas experiências, que incluíram sua participação em uma ONG e em algumas atividades religiosas de diferentes denominações. Para exemplificar esse tipo de percurso, há o caso do jovem Norberto, para quem as experiências de trabalho foram significativas em seu processo de socialização política e de transformação das disposições ao engajamento em efetiva ação militante.

\footnotetext{
${ }^{12}$ Sophie Maurer (2000) considera que a família e a escola são duas instâncias privilegiadas para o estudo da socialização por serem responsáveis pela formação e pela educação de crianças e jovens, razão pela qual teriam mais importância que os meios de comunicação, os pares ou o contexto de inserção do indivíduo. Entretanto, ganhariam centralidade também pela dificuldade de se medir o efeito cognitivo da mídia e do contexto na formação de atitudes, comportamentos políticos e representações de mundo.
} 


\section{pro·posıções

Norberto é natural do estado de Minas Gerais, de família de classe média, que costumava se mobilizar em épocas de campanhas eleitorais para debater e defender seus candidatos, em geral do Partido dos Trabalhadores. Norberto cursou Ensino Médio técnico e, ao concluir essa etapa de ensino, resolveu experimentar sua independência, comunicando aos pais que se mudaria para o Rio de Janeiro. Os pais não teriam apoiado a ideia do filho e, por isso, não lhe deram qualquer apoio financeiro para a viagem. Viveu em pensões, fez "bicos", panfletagens e trabalhou como atendente de uma pizzaria. Na pizzaria brigou com seu empregador por considerar injusta a remuneração dos trabalhadores que ganhavam mais com gorjetas do que com o salário fixo. Foi demitido e virou camelô em bairro do subúrbio carioca. A atividade de camelô era seguidamente reprimida pela polícia e pela guarda municipal. O jovem afirmou que perder mercadorias para o "rapa" da polícia era uma constante e que alguns ambulantes da região resolveram fazer reuniões para tentar encontrar uma maneira de trabalhar sem ter tantos prejuízos e sem sofrer tantas pressões e perdas. " $A i$ eu comecei a me organizar com eles. Ai foi minha primeira experiência com organização, foi com os camelôs". $\mathrm{Na}$ organização, ganhou destaque com os camelôs e foi se transformando em liderança.

A mudança de vida, de acordo com os relatos do jovem, foi significativa - da saída da casa de classe média dos pais para o trabalho como camelô e a hospedagem em pensões de subúrbio. Mas a convivência com pais que declaravam voto e defendiam candidatos e, portanto, falavam de política, certamente construiu disposições ao engajamento, que foram acionadas, mas amplamente reforçadas, na experiência de vendedor ambulante. Fez cursinho pré-vestibular - anunciava o cursinho em sua banca de vendas e, em troca, frequentava gratuitamente o curso - e passou no vestibular de duas universidades públicas. Escolheu uma e, depois de cursado o primeiro semestre, deixou de ser camelô, dedicando-se ao curso universitário, ao movimento estudantil que na universidade encontrou e às atividades do partido no qual se engajou através do movimento estudantil universitário.

As narrativas dos jovens dão conta da formação de um mosaico de espaços e tempos de socialização que ocorrem na família e na escola por diferentes agentes - pais, tios, professores, colegas. Valores internalizados no âmbito familiar podem ser ressignificados, a partir das interações estabelecidas na escola, e o grupo de pares é importante para a construção do engajamento, assim como são alguns professores. Ou seja, as interações são significativas para os jovens, tanto quando ocorrem com os pares de idade quanto com 


\section{pro.posıções

adultos. As trocas de experiências entre pares e com adultos têm significados distintos e pesos também diferentes nos mosaicos que cada jovem constrói.

Assim, somente pelo rompimento com a clássica dicotomia que situa as razões do engajamento entre a estrutura e a estratégia, é que é possível explicar o engajamento dos jovens em partidos políticos. A complexidade dos fenômenos sociais que produzem o engajamento demanda uma possibilidade analítica que permita esclarecer os modos como se constroem as disposições, as competências e as possibilidades de engajamento (Fillieule, 2001; Oliveira, 2005; Seidl, 2009). A articulação das análises das disposições e das interações no presente também permite compreender a maneira pela qual uma disposição se transforma em ação concreta.

\section{Percursos militantes}

As experiências escolares, que contribuíram para a construção de disposições ao engajamento em muitos casos, também representaram o espaço-tempo de conversão das disposições em engajamento. Existência de grêmios estudantis, grupos organizados de estudantes militantes de partidos políticos, mobilizações a partir da escola que aproximaram de organizações partidárias, são exemplos de espaços-tempos da educação básica que permitiram o engajamento de alguns dos 21 jovens entrevistados. Para outros a transformação das disposições em engajamento só se deu no Ensino Superior em espaços similares, ou seja, pela aproximação a centros acadêmicos de seus cursos ou do Diretório Central de Estudantes, a grupos políticos organizados na universidade ou a grupos políticos aos quais chegaram através de atividades universitárias.

Há tempos diferentes de militância, que variam de 6 meses a $14 \operatorname{anos}^{13}$. Gênero, classe e disposições ao engajamento são clivagens que perpassam toda a análise da experiência militante, mas aqui será tomada a dimensão do tempo como central na medida em que permite maior aprofundamento de análises no que tange à transformação de disposições em engajamento e também o alcance do artigo que não permitiria o necessário aprofundamento de todas as dimensões anteriormente citadas. O início da militância ainda no Ensino

${ }^{13}$ Considerando o ano de 2009, quando a primeira etapa de entrevistas foi realizada. 


\section{pro·posıções

Fundamental caracteriza percursos mais longos na militância, mas também jovens que iniciaram militância já na universidade têm percursos militantes de longa duração. Dos 21 jovens entrevistados, 10 iniciaram sua militância quando ainda estavam na educação básica Ensino Fundamental ou Médio - e 11 quando estavam na universidade. Consideraram-se, em função do conjunto de experiências narradas, percursos de mais de cinco anos como de longa de duração, e os de menos de cinco como percursos recentes. Contudo, percursos recentes também podem ser sinônimo de grande investimento militante.

\section{Percursos militantes de longa duração}

Apesar de serem ainda jovens, quando se poderia esperar engajamento relativamente recente, 13 estavam engajados em partidos políticos há mais de 5 anos, sendo que 8 iniciaram militância quando estavam no Ensino Fundamental ou Médio e 5, quando já estavam na universidade.

Dos oito jovens que iniciaram militância quando estavam no ensino básico (Ademir, Julião, Cíntia, Erivelto, Joana, Silvano, Guinevere e Luciano), quatro são oriundos de famílias de camadas populares e quatro de famílias de camadas médias ou elites intelectuais, havendo, portanto, equilíbrio quanto à origem de classe entre jovens que militavam há mais tempo e iniciaram seu engajamento entre os 13 e os 16 anos de idade. No que se refere às socializações familiares, dois jovens tiveram pais engajados, três são de famílias que manifestavam algum interesse político e outros três são de famílias não engajadas. Com exceção de Joana, todos iniciaram sua militância através do movimento estudantil secundarista e logo se envolveram em grupos vinculados a partidos políticos. A filiação partidária após o engajamento estudantil demorou até dois anos para acontecer, mas o envolvimento com os partidos foi quase simultâneo à entrada no movimento estudantil, por meio dos grêmios escolares.

Luciano, de família não engajada e experiência escolar que socializou para a política, disse ter tido vontade de se engajar desde o Ensino Fundamental, mas apenas ao chegar ao Ensino Médio, em nova escola, encontrou espaço de militância. A escola técnica federal onde se matriculou tinha um grêmio mobilizado e vários grupos partidários atuantes. 


\section{pro.posıções

Encontrei tanto um movimento estudantil bem organizado quanto uma gama vastamente grande de organizações políticas e partidos políticos. Tinha uns quatro a cinco partidos políticos organizados com atuação na escola. E ai eu fui participando, tempo depois eu fui fazendo opcões dentro do movimento, dentro do espectro partidário. ... Por estar numa escola que tinha um espectro partidário amplo, digamos assim, eu começo a discutir com essas organizações políticas e muitas fazem um debate muito de propaganda e pouco debate programático, o que seria o programa que elas defendem... Algumas aprofundaram um pouco mais esse debate de programa e eu acabei optando por ficar próximo de uma, e depois de um, dois anos eu acabei que fui fazendo uma discussão mais longa e acabei entrando pra essa organização. (Luciano, PSOL)

O jovem iniciou o Ensino Médio em 1998, engajando-se quase imediatamente no movimento estudantil. Filiou-se ao PT em 2000, numa corrente específica, e nela militou ao longo de todo o Ensino Médio.

O caminho trilhado por Luciano até o engajamento em partido político ilustra a superação de determinadas barreiras ao engajamento que são enfrentadas por alguns jovens para que disposições efetivamente se transformem em prática. Segundo Klandermans (1984), uma pessoa, para se engajar, precisa conhecer oportunidades para fazê-lo, ser capaz de lançar mão dessas oportunidades e estar disposta a isso. A maioria dos jovens entrevistados encontrou oportunidades de engajamento no movimento estudantil. Para alguns, o movimento esteve facilmente ao alcance de suas disposições; para outros, foi preciso encontrá-lo. No caso de Luciano, embora ele já tivesse disposição para o engajamento desde o Ensino Fundamental, a oportunidade só se apresentou no Ensino Médio. Ele lançou mão dela, mas teve que enfrentar a oposição dos pais. A remoção das barreiras à participação é, também, condição necessária ao engajamento.

O engajamento realizado em grupo - junto com colegas de escola - ou a construção prévia de amizades com militantes, para a posterior concretização dos engajamentos nos partidos, também caracterizam a militância dos jovens entrevistados. Poucos foram os que se lançaram sozinhos no engajamento. Julião se engajou no movimento estudantil (ME) junto com colegas de turma, quando o grêmio foi criado em sua escola; Cláudio se engajou junto com seu ex-colega de escola, que estudava na mesma universidade que ele; Luciano conheceu os integrantes do grêmio, estabeleceu vínculos e, só depois, se engajou efetivamente. Retomando Klandermans e Oegema (1987) e os quatro aspectos distintos que contribuem para a concretização do engajamento, listados anteriormente, temos que a formação de potenciais disposições e a formação e ativação de redes de mobilização são fundamentais para que as motivações ao engajamento sejam ativadas e as barreiras removidas. 


\section{pro·posıções \\ $e$-ISSN 1980-6248}

http://dx.doi.org/10.1590/1980-6248-2016-0120

Além dos oito jovens aqui citados, há outros cinco de militância longa, iniciada quando estavam no Ensino Superior. Apesar do início mais tardio, no que se refere ao ciclo escolar, esses jovens também já militavam há bastante tempo e três deles (Cláudio, Tuco e Denise) já haviam se formado e dado prosseguimento aos estudos em nível de mestrado ou iniciaram nova graduação. Tamara e Norberto prolongaram a permanência na universidade, devido a transferências e mudanças de curso e por levarem os cursos em ritmo mais lento, em função da dedicação à militância partidária. Claudio, Tamara e Norberto são de famílias que manifestavam algum interesse por política, e Tuco e Denise provêm de famílias não engajadas. À exceção de Tamara, de camada popular, os outros quatro jovens são de classe média.

Norberto, Cláudio e Tamara se aproximaram gradativamente do movimento estudantil universitário, e todos se vincularam logo a grupos estudantis associados a partidos políticos PT para os dois primeiros e PSTU para a terceira. Norberto vinha da experiência de mobilização dos trabalhadores ambulantes e, pouco tempo depois de entrar na universidade, já conhecia estudantes ligados ao movimento estudantil de seu curso e do DCE. Cláudio já tinha participado de algumas reuniões do PT quando cursava o Ensino Médio e não se engajou. Na universidade, junto com um amigo e colega de Ensino Médio, se vinculou a um grupo de estudantes que se declarava libertários. "É porque não eram justamente anarquistas, nem autonomistas no sentido clássico. Eram independentes, 'porra-loucas'. Mais próximo do anarquismo, [faria] uma crítica à autoridade geral e tudo mais, mas não eram anarquistas ... Então, a gente funda o coletivo" (Cláudio, PSOL). Apesar de ser um grupo declaradamente não partidário, havia, entre seus integrantes, alguns filiados ao PT. Passado cerca de um ano, Cláudio também se filiou, assim como alguns companheiros já tinham feito. Os dois jovens - Cláudio e Norberto - se filiaram ao PT, ambos em 2002, e depois mudaram para o PSOL.

Denise não teve socialização - familiar e escolar - que pudesse dar indícios de construção de disposições ao engajamento. E o modo como chegou até o movimento estudantil também aponta para a ausência de disposições prévias, ao afirmar que foi uma demanda bastante específica e particular que a fez buscar o DCE da universidade.

E aí, eu comecei a me deparar com questões que eu nunca tinha pensando, né? Ah, tipo a luta pela moradia, porque eu morava numa república e pagava um aluguel, e moravam várias pessoas pra esse aluguel ficar mais barato. A discussão de universidade mesmo, ciência e tecnologia... O que se produz. na universidade, como se constrói uma universidade, pra que esse conhecimento é construido. (Denise, PSTU) 


\section{pro.posıções \\ $e$-ISSN 1980-6248}

http://dx.doi.org/10.1590/1980-6248-2016-0120

Um evento aproximou a jovem do DCE - o sentimento de ter sofrido uma injustiça por parte de um professor fez com que a jovem buscasse apoio em seu pleito. Ao conquistar seu objetivo, aproximou-se das pessoas que a ajudaram e construiu novas amizades. Passou a frequentar sistematicamente o DCE e as atividades realizadas pelo diretório central. Assim, foi se enredando e acabou filiada ao partido que estava majoritariamente representado no DCE o PT. Seu engajamento ocorreu "mais ou menos no ano de 2001". A jovem tanto mudou de curso quanto de partido no qual milita. Na "crise do PT" que levou à criação do PSOL em 2005 iniciou participação no partido que estava sendo criado, mas afirmou que não encontrou lá as mudanças que achava necessárias; deslocou, então, sua filiação e seu engajamento para o PSTU.

O percurso de Denise mostra a importância de estruturas que exponham os sujeitos à participação, como afirmam McAdam e Paulsen (1993), na medida em que a jovem não havia tido experiências familiares e escolares significativas para a construção de disposições, ainda que tivesse aprendido, em família, valores rígidos e a noção de ética e respeito. Sentir-se injustiçada por um professor acionou suas disposições referidas a valores éticos e moveu-a em busca de apoio, encontrado no DCE. Isso mobilizou a construção de uma nova rede de amizades, que a expuseram gradativamente ao mundo da política e do engajamento que se concretizou no mesmo espaço em que foram construídas as disposições, de maneira quase simultânea. No caso de Claudio, de forma distinta, as amizades construídas anteriormente - o colega de escola - foram determinantes do percurso de engajamento, bem como das mudanças relativas ao espaço de engajamento - deslocamento do PT para o PSOL.

Entre os jovens de percursos longevos de militância, há tanto aqueles que percorreram caminhos similares de chegada ao partido, quanto os que seguiram diferentes maneiras de chegar lá. Muitos chegaram via movimento estudantil, mas associam-se a isso afinidades com amigos, afinidades programáticas ou ideológicas com os partidos "disponíveis" 14 , heranças familiares ou, ainda, eventos e demandas pessoais. Dois jovens chegaram aos partidos sem intermediação do movimento estudantil e, coincidentemente, ambos são filiados ao PDT.

\footnotetext{
14 Partidos disponíveis significam aqui partidos com presença nos movimentos e núcleos estudantis (escolas e cursos universitários) onde estavam os jovens.
} 


\section{pro·posıções

\section{Percursos militantes recentes}

São oito os jovens com percursos militantes mais recentes (Marina, Nubia, Antonia, Fernanda, Roberto, Mariano e Welington), ou seja, tempo de militância partidária de até cinco anos. Apenas dois deles iniciaram sua militância quando estavam no ensino básico e seis a iniciaram na universidade. Duas jovens são da elite intelectual e de famílias engajadas, uma é de camada média e de família com algum interesse político e quatro jovens são de camadas populares, sendo três deles de famílias com algum interesse político e um de família não engajada.

Enquanto grande parte dos percursos de maior tempo de existência eram constituídos, em sua maioria, por jovens que iniciaram o engajamento no ensino básico, os percursos mais recentes coincidem com a iniciação mais tardia do engajamento, acontecida na universidade, Exceções são Marina e Núbia. No caso de Núbia, a transformação das disposições em prática ocorreu cedo, quando ainda estava no Ensino Médio. O fato é que ela é a mais jovem entre todos os entrevistados e, por isso, sua militância é mais recente, ainda que tenha iniciado cedo seu engajamento. No caso de Marina, suas disposições se transformaram tardiamente em ação, porque apenas na universidade encontrou um espaço organizado de engajamento, que não existiu ao longo de sua escolarização básica. No grupo de jovens de percursos mais recentes, também há maior presença de jovens oriundos de famílias sobre as quais relataram pouca ou nenhuma porosidade ao universo da política ou formas de engajamento.

Roberto é o jovem que formou disposições ao engajamento nas práticas religiosas de uma igreja protestante e atualizou tais disposições quando fez um cursinho pré-vestibular. No cursinho conheceu pessoas ligadas ao PT e ao PCdoB e disse que "não encontrou afinidades" com elas. Chegando à universidade, estava decidido a buscar outros grupos políticos para descobrir com qual teria afinidade e neste se engajaria. Segundo ele, era uma ideia fixa e elaborada antes da chegada à universidade: encontrar um grupo político ao qual se filiar e tornar-se um militante.

Este jovem foi um dos poucos, com militância em movimento estudantil, que não fez "estágio" no ME antes de se filiar a um partido. Os dois engajamentos foram efetivamente simultâneos. "Na verdade, eu vim pra universidade no intuito de procurar os partidos de esquerda, atuais partidos no campo da esquerda do país". Buscou encontrar grupos ligados ao PSTU, ao PSOL e ao 


\section{pro.posıções

PCB, pois o PT e o PCdoB já tinham sido desconsiderados de sua lista de partidos, a partir da convivência com os professores do cursinho. Não encontrou ninguém do PCB, e com o PSTU não teve afinidade. Passou, então, a participar das atividades de uma corrente do PSOL. Se, por um lado, não teve no movimento estudantil um período de experiência, por outro, usou seu primeiro semestre de aulas para experimentar os diferentes grupos de estudantes vinculados a partidos, para melhor escolher o partido ao qual se filiaria e onde se engajaria.

O percurso solitário de Roberto em busca de um partido ao qual se engajar se assemelha muito ao percurso de Tuco. Ambos se fižram sožinhos, no sentido de não terem contado com colegas de escola ou apoio explícito de professores, nem com socialização familiar que apontasse caminhos a partir da transmissão de valores e comportamentos políticos claros. Foram construindo referências com base em experiências e informações difusas e, assim, definiram a que partido se filiariam. Klandermans (1984), Klandermans e Oegema (1987) e McAdam e Paulsen (1993) atribuem grande importância às redes de relações na transformação de disposições em ação, e isso é perceptível na experiência militante dos demais jovens, mas, no caso de Roberto e Tuco, as redes foram se formando à medida que os jovens decidiam qual caminho pretendiam trilhar. Essas redes foram fundamentais para a permanência deles no grupo, mas não foram as determinantes do início do engajamento.

Os grêmios estudantis foram o lugar de concretização das primeiras mobilizações e engajamentos para vários jovens, mas não são necessariamente os agentes de transformação de disposições em ação, visto que alguns deles relataram a existência de grêmios em suas escolas, dos quais não se aproximaram. Julião, Ademir, Núbia, Cíntia e Silvano começaram a participar dos grêmios escolares ainda no Ensino Fundamental e Luciano, Welington, Erivelto e Guinevere participaram de grêmios estudantis no Ensino Médio. Mas Fernanda, Mariano, Cláudio e Tuco disseram que suas escolas tinham grêmios, mas eles não se envolveram em suas atividades. Esses percursos apontam, assim, para a dupla necessidade de existência de estruturas que permitam o engajamento, mas também que ativem motivações para obtê-lo, ou seja, algo que desperte o interesse, que acione as disposições e as transforme em envolvimento. As estruturas não são, per se, suficientes para acionar disposições. É preciso conjugar disposições, estruturas e motivações. Esses jovens disseram que os grêmios tinham pouca visibilidade e não despertaram seu interesse. Ou seja, o grêmio, como outros espaços de engajamento, precisa atrair, oferecendo possibilidades de identificação aos alunos para que 


\section{pro·posıções

participem. Do contrário, os adolescentes e jovens seguem seu percurso escolar sem se comprometer com essas organizações estudantis.

Uma característica escolar que poderia ser fortemente relacionada à construção de disposições, contudo, não foi citada pelos jovens: a gestão democrática, com a participação de todos os atores da instituição nas decisões sobre a política escolar. Talvez tenha existido, mas não foi significativa para os jovens a ponto de ser mencionada como experiência importante no período de escolarização. Mesmo os debates relacionados à conjuntura ou a fatos políticos específicos eram descritos não como prática da instituição escolar, mas atribuídos, pelos jovens, a professores isolados.

Portanto, a escola aparece, nas narrativas dos jovens, não necessariamente como lugar de aprendizagem da política stricto sensu, mas como espaço-tempo ampliado de socialização política, de transmissão e absorção de valores e comportamentos políticos, através das interações entre alunos, entre eles e seus professores e os demais atores do núcleo escolar. Assim sendo, escolarização, socialização política e possibilidades de engajamento se relacionam diretamente com a maior ou menor possibilidade de viver experiências variadas no âmbito escolar e também com as chances de ampliar o grupo de convívio por meio dos colegas da escola. Também pesa a forma como professores e outros atores da instituição interagem com os alunos.

\section{Considerações finais}

No estudo dos engajamentos, os conceitos de socialização e disposição não são suficientes para explicar como os sujeitos efetivamente se tornam militantes, ou seja, como transformam as disposições adquiridas através da socialização política em ação militante.

Articula-se, portanto, à análise diacrônica dos engajamentos, uma dimensão sincrônica, que se revela nas interações vividas pelo sujeito no presente ou no passado próximo. As redes de interação seriam os agentes da ativação e da transformação das disposições em prática. As redes de relacionamentos construídas na escola, na universidade, no trabalho, entre o grupo de amigos e na prática religiosa apareceram como os elementos que ativaram as disposições. 


\section{pro.posıções \\ $e$-ISSN 1980-6248}

http://dx.doi.org/10.1590/1980-6248-2016-0120

Os jovens cujos pais eram militantes tiveram uma socialização claramente influenciada pelos valores políticos dos pais e foram também os que acionaram suas disposições mais precocemente, ou seja, são os jovens de socialização política familiar os que mais cedo se tornaram militantes - com exceção de um jovem cuja família não era engajada e que iniciou cedo a militância, levado por acontecimentos escolares e não pela socialização familiar.

O grupo de jovens de famílias engajadas reúne as elites intelectuais, com exceção de um jovem de classes populares, mas os outros dois grupos - famílias porosas ao tema e famílias desengajadas - têm composição equilibrada entre camadas médias e populares, o que impede de dizer que as famílias de uma ou outra origem de classes estariam mais propensas ao engajamento. As experiências escolares são igualmente variadas, mas a presença de grêmios é um dos elementos significativos para os jovens entrevistados, no que diz respeito à aproximação com o tema da política e do engajamento. A maioria dos jovens que estudaram em escolas com grêmios começou a militar em partidos através do movimento estudantil secundarista, ainda no ensino básico. Poucos foram aqueles que, tendo grêmio em sua escola, não se aproximaram dele. O engajamento e o não engajamento nos grêmios estudantis mostram, a um só tempo, que a existência de espaços que atualizem disposições e as transformem em engajamento é fundamental, mas não suficiente. É preciso haver identificação com os espaços de engajamento disponíveis. Alguns produziram identificações com o grêmio estudantil e já tinham disposições ao engajamento suficientemente consolidadas para transformá-las em efetiva ação militante. Aqueles que não se engajaram em grêmio estudantil, apesar de sua existência, mostram que ou não houve identificação ou ainda não tinham disposições que permitissem o engajamento, o que ocorreu mais tarde e por outras vias/espaços.

Os jovens de famílias engajadas iniciaram militância no grêmio estudantil quando ainda estavam no Ensino Fundamental, e isso foi considerado precoce por eles próprios. Essa característica reforça os limites das interpretações que se baseiam exclusivamente nas disposições duráveis produzidas por processos de socialização - análises diacrônicas - como explicativas de engajamentos. A origem de classe, isoladamente, não explica a transformação de disposições em ação desses jovens, visto que são tanto jovens de camadas populares quanto de classes médias e elites intelectuais que se engajam, em tempos e espaços que igualmente não podem ser definidos por condições de origem de classe. Por outro lado, a exclusiva 


\section{pro-posıções}

http://dx.doi.org/10.1590/1980-6248-2016-0120

abordagem sincrônica é insuficiente para explicar o engajamento mais precoce dos jovens de elites intelectuais.

O grupo de pares ganha peso na transformação de disposições em ação, especialmente quando as disposições são menos evidentes, entre os jovens de mais frágil socialização política familiar, a escola ou os colegas ganharam centralidade na construção de disposições e também na transformação delas em ação. Cláudio encontrou afinidades políticas com um colega de escola, frequentaram reuniões de partido juntos, se afastaram do partido juntos e voltaram a se engajar juntos, ao entrar para a mesma universidade. Amizade e militância caminharam lado a lado na filiação, na mudança de partido e é assim até os dias atuais.

A escola - de Ensino Fundamental, Médio ou Superior - representou, para os jovens entrevistados, tanto espaço de socialização política e construção de disposições ao engajamento quanto lugar de transformação dessas disposições em ação. Klandermans e Oegema (1987) afirmam que as redes de relacionamento são fundamentais para que as disposições sejam acionadas e transformadas em ação, e McAdam e Paulsen (1993) pontuam que, além disso, são necessárias condições estruturais para o engajamento, ou seja, se não houver estruturas que exponham os sujeitos à participação (espaços, grupos organizados localizáveis), as disposições terão pouca importância, porque permanecerão inativas. A escola ou a universidade, para a maioria dos jovens, ofereceu as estruturas que os expuseram ao engajamento - o movimento estudantil e sua interface com os partidos políticos. 


\section{pro-posıções \\ $e$-ISSN 1980-6248}

http://dx.doi.org/10.1590/1980-6248-2016-0120

\section{Referências}

Agrikoliansky, E. (2001). Carrières militantes, et vocation à la morale: les militants de la Ligue des droits de l'homme dans les années 1980. Revue française de science politique, 51(1), 27 46.

Bourdieu, P. (1983). Questões de Sociologia. Rio de Janeiro: Marco Zero.

Bourdieu, P. (1989). O poder simbólico. Rio de Janeiro: Bertrand/ Difel.

Brenner, A. K. (2011). Militância de jovens em partidos políticos: um estudo de caso com universitários. Tese de Doutorado, Faculdade de Educação, Universidade de São Paulo, São Paulo.

Brenner, A. K. (2014). Jovens e militância política. In P. Carrano, \& O. Favero. Narrativas juvenis e espaços públicos: olhares de pesquisas em educação, midia e ciências sociais. Niterói: Editora da UFF.

Cicchelli, V. (2009). The contemporary engagement of young people in France: normative injunctions, institutional programas and the multiplying forms of grouping. Italian Journal of Sociology of Education, 2, 104-127.

Dubar, C. (2005). A socialização: construção das identidades sociais e profissionais. São Paulo: Martins Fontes.

Fillieule, O. (2001). Propositions pour une analyse processuelle de l'engagement individuel. Revue française de science politique, 51(1), 199-215.

Gaxie, D. (2002, avril/juin). Appréhensions du politique et mobilisations des expériences sociales. Revue française de science politique, 52(2-3), 145-178.

Klandermans, B. (1984). Mobilization and participation: social-psychological expansions of resource mobilizations theory. American Sociological Review, 49, 583-600.

Klandermans, B., \& Oegema, D. (1987). Potencials, networks, motivations and barriers: steps towards participation in social movements. American Sociological Review, 52, 519-531.

Maurer, S. (2000). Ecole, famille et politique: socialisations politiques et apprentissage de la citoyenneté. Bilan des recherches en science politique. Dossier d'Etude, 15, 1-75. 


\section{pro-posıçōes

McAdam, D., \& Paulsen, R. (1993). Specifying the relationship between social network and activism. The American Journal Of Sociology, 99(3), 640-667.

Moreno, G. G. (2014). "Tudo que a gente faz na quebrada é política”: vida associativa nas bordas da cidade. Tese de Doutorado, Faculdade de Educação, Universidade de São Paulo, São Paulo.

Müxel, A. (2008, Junio). Continuidades y rupturas de la experiencia política juvenil. Revista de Estudios de Juventud, 81, 31-44.

Oliveira, W. J. (2005) Paixão pela natureza. Atuação profissional e participação na defesa de causas ambientais no Rio Grande do Sul entre 1970 e inicio dos anos 2000. Tese de Doutorado em Antropologia, Universidade Federal do Rio Grande do Sul.

Pécchu, C. (2001). Les générations militantes à Droit au logement. Revue Française de Science Politique, 51(1), 73-103.

Pudal, B. (2009). Da militância ao estudo do militantismo: a trajetória de um politólogo. Entrevista concedida a Kimi Tomizaki. Pro-Posições, 20(2), 129-138.

Ruskowski, B. D. O. (2012). Do incômodo à ação beneficente e da indignação à ação contestatória: estudo sobre condições e mecanismos de engajamento nas Tribos, nas Trilhas da Cidadania e no Levante Popular da Juventude. Dissertação de Mestrado, Programa de Pós-Graduação em Sociologia, Universidade Federal do Rio Grande do Sul, Porto Alegre.

Seidl, E. (2009, maio/agosto). Disposições a militar e lógica de investimentos militantes. ProPosições, 20 (2), 21-39.

Seidl, E. (2014). Engajamentos e investimentos militantes: elementos para discussão. In P. Carrano, \& O. Favero (Orgs.), Narrativas juvenis e espaços públicos: olhares de pesquisa em educação, mídia e ciências sociais (pp. 55-70). Niterói: Editora da UFF.

Silva, A. B. P. (2015). "Nada deve parecer impossivel de mudar": Juventude e engajamento na "Primavera Carioca” das eleições de 2012. Dissertação de Mestrado, Programa de Pós-Graduação em Ciências Sociais, Universidade Federal Rural do Rio de Janeiro, Rio de Janeiro.

Sposito, M., Brenner, A. K., \& Moraes, F. (2009). Estudos sobre jovens na interface com a política. In M. P. Spósito (Coord.), O Estado da Arte sobre juventude na pósgraduação brasileira: Educação, Ciências Sociais e Serviço Social (1999-2006) (pp. 175- 


\section{pro.posições $e$-ISSN 1980-6248}

http://dx.doi.org/10.1590/1980-6248-2016-0120

212, 2 vols.). Belo Horizonte: Argvmentvm. Recuperado em 01 de agosto de 2016, de www.observatoriojovem.org

Tournier, V. (1997). La politique en héritage. Socialisation, famille et politique: bilan critique et analyse empirique. Thèse de Doctorat, Science Politique, IEP Grénoble.

Submetido à avaliação em 9 de agosto de 2016, revisado em 25 de junho de 2017, aceito para publicação em 7 de agosto de 2017. 